\title{
Analysis of Profitability of Groundnut Production in Northern Part of Taraba State, Nigeria
}

\author{
G.B. Taphee \\ Dept. of Agricultural Extension \& Management, \\ College of Agriculture, Jalingo Taraba State, \\ Nigeria.
}

\author{
A.A.U. Jongur \\ Dept. of Agricultural Economics \& Extension, \\ Moddibo Adama University of Technology Yola, \\ Adamawa State, Nigeria
}

\begin{abstract}
The study was carried out to analyse the profitability of groundnut production in Northern Part of Taraba State. The objectives of the study were to: describe the socio-economic characteristics of groundnut farmers, estimate the cost and returns associated with groundnut production and identify the constraints faced by groundnut farmers in the study area. Data were collected with the aid of structured questionnaire administered to 150 randomly selected farmers in the study area. Data generated from the questionnaire were analysed using descriptive statistics and budget techniques. Results revealed that most farmers $75 \%$ are young, mostly females $(57.50 \%)$ and educated (75\%). It also showed that the total revenue (TR), gross margin (GM) and net farm Income (NFI) per hectare were $\$ 100,818.00$, $42,422.00$, and $\$ 41,172$ respectively while the Gross margin per naira invested and net farm income per naira invested were $\$ 0.73$ and $\$ 0.69$ respectively. The problems faced by groundnut farmers include: pest and diseases infestations, insufficient contact by extension agents, shortage of labour, low groundnut prices and inadequate credit facilities among others. The study also recommended that government should re-introduce commodity board and advised that farmers should form cooperatives groups in order to facilitate access to modern farm inputs as well as credit facilities from lending institutions to the farmers in study area.
\end{abstract}

\section{Keywords}

Production, Profitability, Budgetary- Techniques, Groundnut, Taraba

\section{INTRODUCTION}

Groundnuts (Arachis hypogaea $L$ ) also known as peanuts [1]. It is the $13^{\text {th }}$ most important food crop and $4^{\text {th }}$ in oil seed crop of the world. Groundnut seeds (kernels) contain 40-50\% fat, $20-50 \%$ protein and $10-20 \%$ carbohydrates. The seeds are nutritional source of vitamin $\mathrm{E}$, niacin, falacin, calcium, phosphorus, magnesium, zinc, iron, ribloflavin, thiamine and potassium and are consumed directly as raw, roasted or boiled kernels or oil extracted from the kernels is used as culinary oil. It is also used as animal feed (oil pressing, seeds, green materials and straw) and industrial raw material (oil cakes, and fertilizer). The use of groundnut plant makes it an excellent cash crop for domestic markets as well as for foreign trade in several developing and developed countries [2].

\author{
Dengle Yuniyus Giroh \\ Dept. of Agricultural Economics \& Extension, \\ Moddibo Adama University of Technology Yola, \\ Adamawa State, Nigeria \\ Ephraim Ibrahim Jen \\ Dept. of Agricultural Extension \& Management, \\ College of Agriculture, Jalingo Taraba State, \\ Nigeria
}

[3] stated that agro-ecological zones of groundnut are the Sahel $\left(12^{\circ}\right.$ to $\left.13^{\circ} \mathrm{N}\right)$, Sudan $\left(10^{\circ}\right.$ to $\left.13^{\circ} \mathrm{N}\right)$, Northern half of the Northern Guinea savanna $\left(8^{\circ}\right.$ to $\left.11^{\circ} \mathrm{N}\right)$ and most part of the southern Guinea savannah $\left(6^{\circ}\right.$ to $\left.8^{\prime} \mathrm{N}\right)$. Major zones of groundnut are the Sudan and Northern Guinea Savanna where the soil and agro-climatic conditions are favourable. Groundnut which is essentially a tropical plant requires a long and warm growing season. The favourable climate for groundnut is a well distributed rainfall of at least $500 \mathrm{~mm}$ during the crop growing season, and with abundance of sunshine and relatively warm temperature. Temperature in the range of $25^{\circ}$ to $30^{\circ} \mathrm{C}$ is optimum for plant development [4]. A rainfall of 500 to $1000 \mathrm{~mm}$ will allow commercial production.

The agricultural sector's contribution to the Gross Domestic Product (GDP) stood at an average of 56 percent in 1960-64 declined to 47 percent in 1965-69 and further declined to 35 percent in 2003-2004[5]. Groundnut production, marketing and trade served as major sources of employment, income and foreign exchange before Nigeria became independent. The groundnut sector provided the basis for the agro-industrial development and contributed significantly to the commercialization, monetization and integration of the natural rural sector.

Inspite of the availability of abundant land and human resources in Nigeria, yield per from groundnut production has been on the decline over the years. It has been revealed that, there is a shortfall of over 90 percent of groundnut requirement by companies involved in processing [6]. Therefore, there is a need to reverse the foregoing scenario with a view to improving the productivity and efficiency of resources used among groundnut producers through the investigation of the nature of productivity and efficiency in their production.

Cost refers to the value of the inputs used in production while profits are obtained by subtracting the cost from revenue [7]. So, the more one reduces the more the cost. Production is naturally aimed at either maximizing output, maximizing profit, maximize utility; minimize cost or a combination of some of or all of these [8]. There are costs of variable inputs or factors of production such as labour, fertilizer, tools etc while fixed costs refer to the costs of physical assets, such as tractors, buildings, rent, interest on capital and breeding stock [9]. [10] found out that variable costs are those that a manager controls in the short-run and that will increase as total planned production is increased. 
[11] Observed that in the Nigerian agricultural sector, the small operators face pure competition both at production and marketing stages. Because of this structure, output is sold at industry-determined price and profits are maximized at the level of output where marginal cost equals marginal revenue. However, the size of profit depends on how large the per unit output price is compared to the unit cost of production. If the per unit output prices is large, the operators earn pure profit in the short-run. Invariably, if the outcome of the pattern of structure and conduct that is the performance as interpreted by the profit or marketing margins among other things.

[12] In a study of production analysis of groundnut in Ezeagu local Government Area of Enugu State, found out that farmers employed traditional method of farming and use of family labour. He also found out that, groundnut production was a profitable enterprise with a gross margin of $\$ 8,466.00 /$ ha and a sizeable profit of $\$ 6,067.00 / \mathrm{ha}$. According to [13], that transport cost, infrastructural facilities like road network, proximity to market location, price of the commodity and activities of the commercial agents affect profitability of groundnut production in Nigeria. He further stated that groundnut is market in the forms of fresh, dry pods, dry grains and other processed forms.

[14] In a study on the profitability of locally processed groundnut oil and cake discovered that it was a profitable venture, though with a low profit margin, [15] suggested raising the price of groundnut by the government to stimulate producers in order to increase their revenue. They also opined that lowering the prices of inputs would reduce cost of production. A similar view was shared by [16] who said that groundnut producers responded to good prices. On this note, the research was therefore designed to provide answers to the following questions.

(i) What are the socio-economic characteristics of the groundnut farmers in the study area?

(ii) Is groundnut production a profitable enterprise? and

(iii) What are the constraints to groundnut production?

\section{OBJECTIVES OF THE STUDY}

The broad objective of the study was to analyse the profitability of groundnut production in Northern part of Taraba State and the specific objectives were to:

i. describe the socio-economic characteristics of the groundnut farmers in the study area,

ii. estimates the cost and returns associated with groundnut production, and

iii. identify the problems faced by groundnut farmers in the study area.

\section{THE STUDY AREA}

The study was carried out in the Northern part of Taraba State. The state covers a land mass of $59,400 \mathrm{~km}^{2}$ with 16 (sixteen) local government areas. Taraba State lies between latitude $6^{\circ} 30^{\prime}$ and $9^{\circ} 36^{\prime}$ North and longitude $9^{\circ} 10^{\prime}$ and $11^{\circ} 50^{\prime}$ East. It is bounded on the North by Bauchi state and Gombe State in the North-East. It is bounded on the East by Adamawa State and by Plateau State in the North-West. It is further bounded by Benue State in the West and shares an international boundary with the Republic of Cameroon to the south and south-west.

Taraba state has a population figure of 2,300,736 people [17]. The study area is heterogeneous in ethnic composition. The state, as an agrarian state, has a great percentage of its populace engaged in farming as an occupation. Taraba state has a tropical climate, characterized by dry and wet seasons. The rainy season commences early in April to October whereas the dry season starts from November to March. The annual average rainfall in the state ranges between $600 \mathrm{~mm}$ in the North to over $2000 \mathrm{~mm}$ in the south [18]. The climate, soil type and hydrology allow for cultivation of most staple foods, grazing land for animals, fresh water for fishing and forestry. The period for harmattan is a period when the dust laden North-East trade winds from the Sahara Desert have a marked effect on the climate of the state. The period is usually cold and dry and the driest months are January and February when the relative humidity is 13 (thirteen) percent.

\section{METHOD OF DATA COLLECTION}

The data for the research were mainly from primary source. These were obtained through a structured questionnaire, which were distributed to groundnut farmers in the study area. Data collected from farmer covered 2011/2012 cropping season, secondary data/information were also obtained from printed materials such as Journals, textbooks, internet, periodicals, conference proceedings as well as yearly records of production from relevant agencies.

\subsection{Sampling technique}

The study employed multi-stage, purposive, as well as simple random sampling techniques in the selection of respondents. In the first stage, three local government areas out of the six local government areas of Northern part of Taraba State were purposively selected owing to their prominence in groundnut production. In the second stage, two wards each were chosen from each local government area. In the third stage, from the selected wards, two villages were selected proportional to the size of the wards selected as first sampling frame. In the final stage, a list consisting of all the names of groundnut farmers in each of the 12 villages was obtained, numbered and squeezed, this formed the second sampling frame. Then at random, farmers were chosen from each village. A total of 150 farmers were chosen for the study in a ratio proportional to the size of their population.

\subsection{Methods of data analysis}

The methods of data analyses used include: descriptive statistics and budgeting techniques. The budgeting technique was employed to estimate costs and returns from groundnut production for 2011/2012 growing season. The net income is the difference between the gross margin and the total fixed cost. Thus we know that GM is the difference between the value of production and that of total variable cost [19]. The net income analysis is thus used to determine the performance of enterprise, that is, the productive component of a firm to obtain information as pertain the business strength or weakness [20]. [21] also stated that net income involves evaluating the efficiency of individual enterprise. The net income analysis was used to achieve objective two (2) of the study. The value of production was the gross income obtained from groundnut and in Naira/kilogram $(\mathrm{N} / \mathrm{kg})$ whereas the variable costs considered were costs of inputs like fertilizer, labour, transportation, ploughing e.t.c. Mathematically, Gross Margin is given as:

$\mathrm{GM}=\mathrm{GI}-\mathrm{TVC}$

Where:

$\mathrm{GM}=$ Gross Margin (in Naira)

$\mathrm{GI}=$ Gross Income (in Naira)

TVC $=$ Total Variable Cost (in Naira) 
Furthermore Net farm Income was calculated which is given as:

$\mathrm{NFI}=\mathrm{GM}-\mathrm{TFC}$

Where: NFI $=$ Net farm Income (in Naira

TFC $=$ Total Fixed Cost (in Naira)

\section{RESULT AND DISCUSSION \\ 5.1 Socioeconomic Characteristics Of Groundnut Farmers}

The Socioeconomic characteristics of groundnut farmers in the study area revealed that majority $(75 \%)$ of them are relatively young, with mean age of 35 years. Farmers age determines the type of production to be performed, where farmers are younger, they are more likely to be efficient in labour tasking jobs such as weeding, harvesting (picking of the nuts), drying and packaging. The results confirms with the works of [22] who noted that age is one the socioeconomic features that affects the level of productivity. The farmers are mostly (57.50\%) female gender which may not be unconnected with the fact that women are more patience and therefore can endure the labourous aspect of the picking and drying of the groundnuts during harvest periods. Most of the farmers are married $(75.67 \%)$ with only $28.33 \%$ are single.

As for the family size, $66.67 \%$ of the respondents have $1-5$ people in household with mean household size of 5 people. Most of the respondents (58\%) had farm size of 1-2 hectares each which is a characteristic of small scale farmers. The respondents' educational level shows that most farmers (75\%) have acquired one form of formal education or the other, which is on incentives to effective communication and adoption of new technology. The result agreed with the findings of [23], [24] and [25]. Analysis in table 1 also unveiled that the experience of the farmers in farming groundnuts was 6-10 years with mean of 9 years of experience. The expectation is that the farmers will use this experience to manage their groundnut farms better. Most of the farmers $(52 \%)$ were not visited by the extension agents while $48 \%$ were visited by extension agents. The farmer will be very slow in the adoption of agricultural innovations due to lack of frequent contact by change agents. This result is in consonants with the work of [26] who reported that the economic efficiency level of farmers was significantly affected by extension services.

The result revealed that majority $58 \%$ of groundnut farmers used family labour for their production. Thus, the result agreed with the findings of [7] which reported that family labour is the most important component of labour in small holder farmers' production in Nigeria and in most African countries. It is also revealed that majority $(83.33 \%)$ of the respondents used their personal savings to farm while only $9.17 \%$ acquired credit from friends and relatives. The result indicates that that majority of farmers in the study area have little or no access to credit facilities.
Table 1: Socioeconomic characteristics of groundnut farmers

\begin{tabular}{|c|c|c|}
\hline Variable & Freq. & Per. (\%) \\
\hline Age (Years) & \multirow{5}{*}{$\begin{array}{l}17 \\
90 \\
13 \\
\mathbf{1 2 0}\end{array}$} & \multirow{5}{*}{$\begin{array}{l}14 \\
75 \\
11 \\
\mathbf{1 0 0 ( 3 5 )}\end{array}$} \\
\hline $0-3$ & & \\
\hline $31-40$ & & \\
\hline$\geq 41$ & & \\
\hline Total & & \\
\hline Gender & \multirow{4}{*}{$\begin{array}{l}51 \\
69 \\
\mathbf{1 2 0}\end{array}$} & \multirow{4}{*}{$\begin{array}{l}42.50 \\
57.50 \\
\mathbf{1 0 0}\end{array}$} \\
\hline Male & & \\
\hline Female & & \\
\hline Total & & \\
\hline Marital status & \multirow{4}{*}{$\begin{array}{l}86 \\
34 \\
\mathbf{1 2 0}\end{array}$} & \multirow{4}{*}{$\begin{array}{l}71.67 \\
28.33 \\
\mathbf{1 0 0}\end{array}$} \\
\hline Married & & \\
\hline Single & & \\
\hline Total & & \\
\hline Family size (in number) & \multirow{5}{*}{$\begin{array}{l}80 \\
25 \\
15 \\
\mathbf{1 2 0}\end{array}$} & \multirow{5}{*}{$\begin{array}{l}66.67 \\
20.83 \\
12.50 \\
\mathbf{1 0 0 ( 5 )}\end{array}$} \\
\hline $1-5$ & & \\
\hline $6-10$ & & \\
\hline$\geq 11$ & & \\
\hline Total & & \\
\hline Literacy level & \multirow{6}{*}{$\begin{array}{l}30 \\
35 \\
30 \\
25 \\
\mathbf{1 2 0}\end{array}$} & \multirow{6}{*}{$\begin{array}{l}25 \\
29 \\
25 \\
21 \\
\mathbf{1 0 0}\end{array}$} \\
\hline No formal education & & \\
\hline Primary education & & \\
\hline Secondary education & & \\
\hline Tertiary education & & \\
\hline Total & & \\
\hline Farming experience (years) & \multirow{5}{*}{$\begin{array}{l}25 \\
80 \\
15 \\
\mathbf{1 2 0}\end{array}$} & \multirow{5}{*}{$\begin{array}{l}20.83 \\
66.67 \\
12.50 \\
\mathbf{1 0 0}\end{array}$} \\
\hline $1-5$ & & \\
\hline $6-10$ & & \\
\hline$\geq 11$ & & \\
\hline Total & & \\
\hline Type of labour & \multirow{5}{*}{$\begin{array}{l}70 \\
20 \\
30 \\
\mathbf{1 2 0}\end{array}$} & \multirow{5}{*}{$\begin{array}{l}58 \\
17 \\
25 \\
\mathbf{1 0 0}\end{array}$} \\
\hline Family labour & & \\
\hline Hired labour & & \\
\hline Both & & \\
\hline Total & & \\
\hline Source of credit facilities & & \multirow{5}{*}{$\begin{array}{l}83.33 \\
9.17 \\
7.50 \\
\mathbf{1 0 0}\end{array}$} \\
\hline Personal savings & & \\
\hline Friends and Relatives & & \\
\hline Others & & \\
\hline Total & & \\
\hline $\begin{array}{l}\text { No. of contact with } \\
\text { extension agents }\end{array}$ & \multirow{6}{*}{$\begin{array}{l}62 \\
28 \\
22 \\
8 \\
\mathbf{1 2 0} \\
\end{array}$} & \multirow{6}{*}{$\begin{array}{l}52 \\
23 \\
18 \\
7 \\
\mathbf{1 0 0} \\
\end{array}$} \\
\hline No visit & & \\
\hline Once per week & & \\
\hline Twice per week & & \\
\hline Thrice per week & & \\
\hline Total & & \\
\hline
\end{tabular}

Source: Field survey, 2012

Note: Value in parenthesis is the mean value

\subsection{Profitability analysis}

The Net Income analysis for groundnut farmers is shown in Table 2. The average variable cost/ha was $\$ 58,396.00$ which represents $97.9 \%$ of the total farming cost, while depreciation on fixed cost was $\$ 1250.00(2.1 \%)$ of the total cost of farming. Thus the total cost (TC) of farming operation/ha was $\$ 59,646$. The total revenue (TR), gross margin (GM) and, net farm income (NFI) per hectare are $\$ 100,818.00, \$ 42,422.00$ and N41,17.00 respectively. Base on the above figures, it is implied that groundnut farming is profitable in the study area. The result agreed with the finding of ${ }^{[12]}$ who carried out a research on the production analysis of groundnut in Ezeagu 
Local Government area of Enugu State and came up with a result that groundnut production is highly profitable. The return on naira invested (R.O.I) by farmers in the study area revealed that for every one naira invested, $\$ 0.73$ and $\$ 0.69$ were gained. This also indicates that groundnut production in the study area is profitable. Therefore this should attract financing by lending institutions. The direct interpretation is that, if the groundnut farmers are financed by commercial lending institutions with say $\$ 30,000.00$ at an interest rate of $18 \%$, based on the return on naira invested above, it means that groundnut farmer will return the principal of $\$ 30,000.00$, interest of $\$ 5,400.00$ and still retain $\$ 17,500.00$ and $\$ 15,300$ as his profits respectively.

Table 2: Average cost and returns of groundnut farmers per hectare

\begin{tabular}{|l|c|}
\hline \multicolumn{1}{|c|}{ Variable } & Values (N/kg) \\
\hline a) Variable Cost & $58,396.00$ \\
\hline b) Depreciation on fixed cost & $1,250.00$ \\
\hline Total cost of Production & $\mathbf{5 9 , 6 4 6 . 0 0}$ \\
\hline c) Returns & \\
\hline Total Average output & $\mathbf{8 4 0 . 1 5 k g}$ \\
\hline Average price/kg & $120.0 / \mathrm{kg}$ \\
\hline Total Revenue & $\mathbf{1 0 0 , 8 1 8 . 0 0}$ \\
\hline Gross Margin (TR-TVC) & $42,422.00$ \\
\hline NFI (GM-TFC) & $41,172.00$ \\
\hline Gross Margin per Naira invested & 0.73 \\
\hline Net farm Income per Naira invested & 0.69 \\
\hline
\end{tabular}

Source: Field Survey, 2012

\subsection{Constraints associated with groundnut production in the study area}

The production constraints of the respondents analysed include: pest and diseases infestation, insufficient extension agents, low groundnut prices, inadequate farm machineries, lack of storage facility, inadequate credit facilities, inaccessibility to cheap farm inputs, land tenure and shortage of labour which are all ranked according to their magnitude. The result of table 3 showed that pests and diseases ranked first as one of the major problems faced by groundnut farmers in the study area. This is represented by $83.33 \%$. Insufficient extension agents ranked second with $79.17 \%$, low groundnut prices is third with $75 \%$, inadequate farm machineries fourth with $72.50 \%$, lack of storage facilities fifth with $70.83 \%$ while inadequate credit facilities, inaccessibility to farm inputs, land tenure and shortage of labour occupied the Sixth, Seventh, Eight and ninth positions with $69.17 \%, 66.67 \%, 43.33 \%$ and $23.33 \%$ respectively. This finding is in conformity with the works of [27],[28] and [29] as well as that of [30] and [31], who stated that Early and late leaf spots commonly called Tick Diseases caused huge yield loss in groundnut due to defoliation and insect pests on groundnut such as Hobner (Heliothis amigera) and aplids have become a serious problem in groundnut in recent years.

The insufficient number of contact by extension agent is prevalent in most community of Nigeria today as one can hardly see a change agent in villages. Even their demonstration plots or SPATs cannot longer be seen these days instead they concentrated themselves in towns and cities where they can enjoy social amenities. This is a serious threat to agricultural growth and development as most farmers cannot apply correctly some agricultural innovations on their farms that require the attention of extension agents. This situation has a devastating effect on the over all economic efficiency level, of farmers as opined by [26]. The research agreed with the findings of [32] who observed that low producer prices and limited modeling opportunities reduced incentives for small holder groundnut farmers to invest in productivity enhancing technologies.

The inadequate farm machineries may probably be the reason why farmers could not expand their land for groundnut production. Thus this conforms to the works of [12] and [33] who identified access to or lack of improved capital inputs as one of the major problems of groundnut production. Lack of storage facilities may be attributed to the reason why farmers dispose off most of their groundnut product at the farm gate and probably the reason why output is sold at industry determine price as observed by [11]. The inadequate credit facilities may be a reason why farmers could not afford to use modern farm inputs such as high yielding seed varieties and improved farm practices such as irrigation and farm management practices as it is identified by [33]. On the inaccessibility of farm inputs by the farmers may probably be the reason why the groundnut producers suffered from production and downward trend. [34] and [3] attributed groundnut production problem to inadequate farm inputs.

The land tenure system may also be a reason why farm size of the respondents is small. This constraint agreed with the work of [36], who stated that although the country is endowed with agricultural land, the right to ownership of the land and ethnic boundaries make it hard for farmers to easily acquire land for agricultural purpose outside their cultural location. The shortage of labour in the study area may be attributed to peasant farming nature of the groundnut farmers. This finding agreed with the works of [35] and [3] that groundnut production problem 'is associated with high labour cost.

Table 3: Distribution of respondents based on constraints associated with groundnut production

\begin{tabular}{|l|c|c|c|}
\hline \multicolumn{1}{|c|}{ Problems } & Freq & $\begin{array}{c}\text { Perc. } \\
(\boldsymbol{\%})\end{array}$ & $\begin{array}{c}\text { Rank } \\
* *\end{array}$ \\
\hline $\begin{array}{l}\text { Pests and diseases } \\
\text { infestation. }\end{array}$ & 100 & 14.29 & 1 \\
\hline $\begin{array}{l}\text { Insufficient contact by } \\
\text { extension Agents. }\end{array}$ & 95 & 13.57 & 2 \\
\hline Low groundnut prices. & 90 & 12.88 & 3 \\
\hline Inadequate farm machineries & 87 & 12.43 & 4 \\
\hline Lack of storage facilities. & 85 & 12.14 & 5 \\
\hline Inadequate credit facilities & 83 & 11.86 & 6 \\
\hline Inaccessibility to farm inputs & 80 & 11.43 & 7 \\
\hline Land tenure & 52 & 7.40 & 8 \\
\hline Shortage of labour & 28 & 4.00 & 9 \\
\hline Total & $700 *$ & $\mathbf{1 0 0 . 0}$ & \\
\hline
\end{tabular}

Source: Field survey, 2012

** Rank in descending order of magnitude

* Multiple responses

\section{CONCLUSION}

The result of the study shows that Females are more engaged in groundnut farming than men. The farmers in the study area are in their active age and literate. Groundnut farming in the study area is profitable. The problems that were found to be associated with groundnut farming in the study area include: pests and diseases infestation, insufficient contact by extension agents, low groundnut prices, inadequate farm machineries, lack of storage facilities, inadequate credit facilities, inaccessibility to farm inputs, land tenure and shortage of labour.

Having known that, the study area is a profitable venture, investors be encouraged to invest and participate in groundnut 
farming. Based on the constraints identified, it will help policy makers to fine-tune ways of ameliorating them for increased production, hence, more profitably the groundnut farmers in the study area and the state at large

\section{REFERENCES}

[1] Beghin, J. Diop, N., Matthey, H. and Sewadah, M. "The impact of Groundnut Trade Liberalization: Implication for the Doha Round". Mimeo, selected paper presented at the 2003 AAEA Annual Meetings, Montreal, .2003.

[2] FAO, “ Production Year Book, Vol. 60”, Rome, Italy, 2006.

[3] Misari, S.M., Harkness, C. and Fowler, M., "Groundnut Production, Utilization, Research Problems and further Research Needs in Nigeria". International workshop on Groundnuts, Paterchern, India, 1980, Pp 264-273. ICRISAT, 1988.

[4] Weiss, E.A., "Oilseed Crops. London: Blackwell Science", 2000.

[5] Amaza, P.S. and Maurice, D.C. "Identification of Factors that Influence Technical Efficiency in Rice-based Production Systems in Nigeria paper promoted at workshop in politics and strategies for promoting Rice Production and Foods Security in sub-Saharan Africa". 7-9 Nov. 2005. Cotonou, 2005.

[6] RMRDC, "Raw Materials Research and Development Council, (Abuja, Report On Survey of selected Agricultural Raw Materials in Nigeria", Groundnut Maiden Edition, October, 2004.

[7] Adegeye, A.J. and Dittoh, J. S., "Essentials of Agricultural Economics". Impact publishers Nigeria Limited. Ibadan 251Pp, 1985.

[8] Olayide, S.O. and Heady, E.O., "Introduction to Agricultural Production Economics University of Ibadan Press, Ibadan, Nigeria. Pp 233-238, 1982.

[9] Olukosi, I.O. and Isitor, S.U. "Introduction to Agricultural Marketing and Price. Principles and Applications". Living Book Series, G.U. publications, Abuja, Nigeria. 116p, 1990.

[10] Spurlock, S.R. and Gillis, W.G. "Costs and Returns for Corn, Cotton, Rice, Soyabean and Wheat in Mississippi, Mississippi Agriculture and Forestry Experience Station Bulletin” 1082 Pp. 1-9, 1977.

[11] Eyo, E.O. "Financing Foodstuff Marketing in AkwaIbom State Nigeria; Some considerations", Global Journal of Agricultural Sciences 3(1-2) 35-40, 2004.

[12] Awoke, M.U. "Production Analysis of (Arachis Huypozaea) in Ezeagu Local Government Area of Enugu State". Global Journal of Agricultural Sciences 2(2): 138-142, 2003.

[13] Langyinto, A.S. "Analysis of the efficiency of Maize Marketing in Northern Ghana". In: Badu Aparaku, B.F., Fakorede, M.A.B., Quedraago M., and Quin, F.N. Strategies for sustainable Maize Production in West and Central Africa. Proceedings of Regional Maize Workshop IITA Cotonou, Benin Republic. Pp. 388-400, 1999.

[14] Hammawa, M. "Economics of Locally Processed Groundnut Oil and Cake in Yola North and South Local Government Areas of Adamawa
State". Unpublished Work Agric. Tech. Project, Department of Agricultural Economics and Extension, Federal University of Technology, Yola, Nigeria, 2001.

[15] Obiesie, B. and Chuke, A.G. "Background to the search for solution to the Groundnut problem". A paper presented at the $20^{\text {th }}$ Annual Conference of the Agricultural Society of Nigeria, Rivers State University of Science and Technology, Port-Harcourt, 19-24 August, 1984.

[16] Abalu, G.O.I. "Supply Response to Producers Process: A case study of Groundnut Supply to Northern States Marketing Board”. Samaru Research Bulletin No. 268. Institute of Agricultural Research Ahmadu Bello University, Zaria Pp 1-15, 1976.

[17] National Population Commission (NPC) "2006 Population Census Figures”, 2006.

[18] TADP "Crop Production Recommendations for Taraba State”, Taraba Press Ltd. Nigeria Pp. 31-39, 2010.

[19] Adebayo, E.F. "Resources Use Efficiency and Multiple Objective of Dairy Pastoralists in Adamawa State, Nigeria". Unpublished Ph.D. Thesis. Department of Agricultural Economics, University of Ibadan, 2006.

[20] Bucket, M. "An introduction to Farm Organization and Management", $2^{\text {nd }}$ Edition, Pergaman Press Oxford Pp. 115, 1988.

[21] Olukosi, I.O. and Erhabor, P.O. "Introduction to Farm Management Economics; Principles and Applications" AGITAB publishers. Zaria, 2005.

[22] Adebayo, E.F. and Onu, J.I. "Economic of rice production in Yola North and South local government area". Nigerian Journal of Tropical Agriculture 1:15-20, 1999.

[23] Alabi, R.A. and Aruna, M.B., "Technical Efficiency of Family Poultry Production in Niger-Delta, Nigeria". Journal of Central European Agriculture, 06(4) 531-535, 2006.

[24] Arnon, I. "Modernization of Agriculture in Developing Countries: Resources, Potentials and Problems". JohnWilley and Son Ltd. U.K. Pp 17 1-423, 1987.

[25] Awoola, M.D. "Education and Farmers Motivation: Case study of fire villages in Zaria Area of Kaduna State". Journal of Rural Development and Administration 27(2) $1-12,1995$.

[26] Adewuyi, S.A. and Okunmadewa, F.Y. "Economic Efficiency of Crop Farmers in Kwara State Nigeria". Nigerian Agricultural Development Studies. 2(1): 45-57, 2001.

[27] Crauford, P.Q. Prasad, P.V.V., Wadiyar, F., Tahore, A. "Drought, Pod Yield, pre-harvest Aspergillus infection and aflatoxin contamination on peanut in Niger, Field Crops", Research 98: 20-29, 2006.

[28] Garba, A., Abdul, S.D., Udom, G.N. and Auwal, B.M "Influence of variety and Intrarow spacing on Cercorpora leaf spot disease of groundnut in Bauchi, Nigeria". Global Journal of Agricultural Sciences 4(2): 177-182, 2005.

[29] Lokhande, N.M. \& Newashar, V.B. "Epidemiology and Forecasting of leaf Spot of Groundnut", In: Proceeding 
of International Conference on Integrated Plant Disease Management for Sustainable Agriculture (Mitra, D.K ed.) Phytopathological Society, New Delhi. Pp. 1281, 2000 .

[30] Upadlyay, V.R., Vyas, H.N. and Sherasiya, R.A "Influence of Weather Parameters on Larval populations of Heliothis armeegera Hubner on groundnut". Indian Journal of Plant Protection 17:85-87, 1989.

[31] ICRISAT “Annual Report”, International Crop Research Institute for Semi-Arid Tropics, Patanchem, India, 1989.

[32] Freeman, H.A., Aligam, S.N. Kelly, T.G., Ntare, B.R Subrahmainiam, P. and Broughton, D. "The World Groundnut Economy; Facts, Trends and Outlook". ICRJSAT, Panta Cheru India, 1999.

[33] Diop, N., John, B., Mirvat, S. "Groundnut Policies, Girbal Trade Dynamics and the Impact of Trade
Liberalization". World Bank Policy Research Working Paper 3226 March, 204, 2004.

[34] Ntare, BR. "Groundnut Pyramids in Nigeria. Can they be Reviewed?" http:// www.ICRISAT.org ............1 Pyramids html, 2005.

[35] Ntare, R.B., Waliyar, F. Ramouch, M., Master, E., and Ndejungar, J. "Markets Projects for Groundnut in West Africa". Common Funds for Communities Standhouders Kade 55, 107AB Amsterdam. The Netherlands, 2005

[36] Abdullahi, A. "The problems and prospects of the Green Revolution for Agriculture and rural development of Nigeria". Technical environmental perspective, Ahmadu Bello University, Zaria, 1981. 